\title{
Trading Halal: Halal Certification and Intra-Muslim Trade in South Africa
}

\author{
Shaheed Tayob \\ Department of Sociology and Social Anthropology, Stellenbosch University, \\ Stellenbosch, South Africa \\ shaheedt@sun.ac.za
}

\begin{abstract}
Halal certification introduces a new discursive and material basis for the regulation of Muslim consumption in a world of global trade and complex food technology. Through chemical tests and state of the art supply chain management the halal certification industry aims to replace the necessity of intra-Muslim trade for the practice of halal. This paper presents the approach of two competing halal certification organizations in South Africa in interaction with Muslim businesses. It argues that the aim of the halal certification industry to standardize, trace and trade in halal is limited by the communal practice of halal that emphasizes intra-Muslim trade and exchange. Halal certification is an incomplete recalibration of halal. Attention to Muslim business practices illuminates the limitation of audit cultures to the practice of halal, offering a view of the complexity of halal in practice.
\end{abstract}

\section{Keywords}

ethics - trust - halal - neoliberalism - certification - standardization - Islam

South Africa presents a unique case study for the global development of halal certification. Muslims comprise approximately $1.5 \%$ of the total population (Schoeman 2017). Yet a 2012 report indicates that up to $60 \%$ of all products on South African supermarket shelves are halal certified. ${ }^{1}$ This means that both Muslims and non-Muslims regularly consume halal certified food including

1 Halal market to top $\$ 3.7$ trillion by 2019. Gulfnews.com. Last accessed 2016. 
both meat and non-meat products. The growth of halal certification has been in part driven by the significant consuming power of the Indian middle-class trader communities in the country. Post-apartheid freedom of movement increased demand for halal goods and services in places previously off-limits to non-white citizens. The de-regulation of the meat industry led to the establishment of private abattoirs and the import of meat from across the globe. Complex food production technology introduces the possibility that even nonmeat products might be non-halal. Together these developments present new opportunities and challenges for halal practice and halal certification in South Africa.

Halal certification emerged as a response to the new conditions of consumer demand, global trade and complex food technology. Together with global organizations, South African halal certification seeks to assure Muslims that they can consume halal even in impersonal markets and non-Muslim contexts. The certification industry emphasizes the necessity for expert intervention and halal auditing procedures in all contexts of Muslim consumption. A new discourse of risk, consumption and certification extends halal beyond meat products to include all items of Muslim use. According to halal certification, all uncertified consumption is a potential source of halal transgression. Halal certification strives for material certainty and trust in the substance of halal to facilitate trade and exchange beyond Muslim contexts. In the process, the homes of friends, family and even Muslim-owned businesses have all become subject to halal certification demands.

For many South African Muslims, nonmeat food products are inherently halal. Trust in the halal quality of meat is established through intra-Muslim trade and exchange. The homes of Muslim friends and family and Muslimowned businesses are necessarily halal, precluding the need for certification or clarification. According to this discursive tradition of halal, it is an offense to doubt the food of a fellow Muslim, and the consumer is absolved from sin if duped by a devious supplier. If both consumer and supplier are unaware of a halal transgression then neither is at fault. Central to this practice of halal is a communally charged notion of trust that emphasizes inter-personal networks of trade and exchange over material certainty. This means that many South African Muslims consume vegetarian food at non-halal certified restaurants and refuse to demand certification of Muslim-owned businesses. In doing so, they challenge the very premise of the halal certification industry in its aim to establish material certainty over halal.

Given the complexity of halal practice, this paper argues that halal certification does not equate to a standardization of halal. Halal certification is a new mode of halal that challenges and seeks to displace another established 
practice of halal. The older discursive tradition is not simply erased by new practices of halal certification. Halal certification organizations, Muslim consumers and Muslim businessmen continue to emphasize the importance of Muslim networks of trade for the practice of halal. This paper therefore addresses the issue of Muslim business certification through an investigation of the modes of trust of halal. The argument in this paper forces closer attention to the ways in which Muslim businesses evade the halal certification industry goal of standardization and its emphasis on procedural compliance.

\section{Halal Certification: Audit Standards and Halal Practice}

Research on the contemporary consumption of halal in minority contexts argues for halal consumption as an expression of national, ethnic, minority and consumer identity (Bonne and Verbeke 2008; Fischer 2011; Gillette 2005; Marranci 2012; Woong 2007). In South Africa it is clear that the process through which halal consumer identities are emerging has to be understood as a process of institutionalization, rationalization and late-modern expert intervention (Tayob 2012). Similarly, in Malaysia, state organizations, scientific laboratories and Islamic organizations converge in the regulation of a certified form of standardized, 'global halal' (Fischer 2016). Neoliberal refers to a standardized, technocratic and bureaucratic form of governance whereby halal is abstracted as a quality that can be measured, traced and investigated in order to facilitate global trade and public consumption beyond local Muslim networks. Muslim consumers now receive a barrage of information about product ingredient listings, food technology codes and manufacturing processes as potential risks to halal (Tayob 2016). The relevance of neoliberal governmentality for an analysis of halal lies in the transformations of knowledge and materiality that give rise to new forms of ethical subjectivity as individuals self-regulate their relation to each other and the world (Foucault 2007).

Arguments for the standardization and rationalization of halal fail to appreciate the complexity of Islam as a discursive tradition. As Talal Asad has argued, contemporary Muslim practice must be understood from within a long history of textual production and everyday practice, 'that connects variously with the formation of moral selves, the manipulation of populations (or resistance to it), and the production of appropriate knowledges' (Asad 1986: 7). What constitutes halal can be counted among these 'appropriate knowledges'. As with other such knowledges, new conditions of knowledge and of politics produce new expressions of Islam. This is always processual, emergent and contested as different actors make divergent claims to the supposed truth of 
Islam. Importantly, this means that debate and difference is internal to Islam. Standardization and homogenization is not a feature of Islam in practice.

In contrast, 'audit cultures' aim for the standardization, rationalization and bureaucratization of the contemporary world (Shore and Wright 1999; Strathern 2000). Audit cultures and critical accounting scholarship compare audit practice to Latour's scientific process of 'fact building' in the laboratory (Power 1996: 309). The audit of quality control requires the establishment of quality control departments that produce documentation testifying to compliance with quality control standards. A quality control audit is the practice of assessing this newly developed documentation. The self-referential nature of audit means that auditing is always liable to circumvention and potential breakdown, evident in the frequent and scandalous contraventions of financial auditing practice.

Laura Bears' study of the globally integrated shipbuilding industry along the Hooghly River in Kolkatta highlights the uneven and unexpected consequences that emerge from the expansion of neoliberal regimes of governmentality and audit culture (Bear 2011). For buyers in Europe, the quality control audit certificate is sufficient testimony to the quality of the final product. Beneath the veneer of documentation and accountability, however, is a complex world of hierarchy, power and charisma. The product may meet a certain level of quality, but to produce it, the informal sector of production is rendered opaque rather than transparent (Bear 2013: 389). For Bear, neoliberal governmentality does not in fact 'create a consensual ethics or subjectivity' in the workplace (Bear 2013: 39o). Bear cautions against the 'rationalizing, standardizing and ordering capabilities' of neoliberal governmentality and audit culture. She calls for attention to audit standards and quality control in practice.

Like quality control audit, halal certification is engaged in a process of 'fact building' in an attempt to achieve certainty over the materiality of halal. DNA tests, supply chain management and documentation are produced in support of halal certification. However, halal certification does not lead to 'abstract indifference to the substance of performance' (Power 1996: 302). The shift to 'molecular halal' introduces a piercing scientific gaze into the materiality of the substance consumed (Tayob 2019). Halal certification claims to obliterate Muslims' dangerous indifference to, or ignorance of, the material substance of consumption by making halal transparent, traceable and stable. However, the material certainty that is supposed to facilitate halal beyond Muslim networks of trade is not complete. Certification organizations and Muslim businesses continue to draw on a discursive tradition of halal rooted in intra-Muslim trade and exchange in the practice of halal. 
Unlike quality control audits where Iso (International Organization for Standardization) standards have become an agreed upon practice for producing trust, halal certification is not uniform. In most parts of the world, there is no centralized state authority for its regulation. Even in Muslim countries, there are no clear agreements between different states on what constitutes halal and how it should be regulated. Finally, and most importantly for this paper, halal practice has historically not depended on technocratic processes of documentation and certification. Muslims have engaged, and continue to engage, in halal practice across large distances and in impersonal markets with no need for testing. Even in Malaysia, with a highly regulated and centralized state department for halal, many Muslim restaurants and businesses refuse to incur the costs and burdens of halal certification (personal communication with Dr. Hew Wai Weng). Being ethnic Malay is synonymous with being Muslim, and identity trumps documentary compliance. The continued articulation of halal with intra-Muslim networks of trade and exchange points to the limits of standardization and individualization when viewed from the longer duree of Muslim consumption and trade. Contemporary halal practice is therefore best seen as an uneven convergence between the new imperatives of food technology, supply chain management and global trade with an established discursive tradition of intra-Muslim trade and exchange.

\section{Halal in Practice: Intra-Muslim Networks, Consumption and Trust}

The practice of halal is a central tenet of Islamic dietary law. Halal, meaning permissible, includes a set of procedures and guidelines through which permissible animals are transformed into meat acceptable for Muslim consumption. Historically there have been regional and sectarian differences regarding the halal status of particular animals (Cook 1986). It has been argued that these differences evolved out of the desire to assert difference or similarity through denial or acceptance of the food of other groups (Freidenreich 2011). The meat of swine and dogs can never be halal, while the permissibility of other animals varies depending on regional and sectarian affiliation. The method of what constitutes halal slaughter is not uniform. For most Muslims, the pronunciation of the name of God before slaughter is the primary pre-requisite. Other recommendations (sunnat) include that the animal is oriented towards Mecca, that a sharp knife is used, and that live animals are kept out of sight of slaughter. For some Muslims, meat can be acceptable even if the name of God has been omitted upon slaughter. For some, acceptable practices of halal include all meat slaughtered by Christians and Jews (ahl-al-kitab). 
In most cases, the consumer of halal meat is not the slaughterer. The practice of halal is therefore premised on a notion of trust and intra-Muslim exchange. The consumer trusts the supplier, who in turn trusts the slaughterer, that the proper procedures of halal have been followed. A rule of thumb prevalent across the Muslim world states that supply by a fellow Muslim constitutes halal. It is considered a personal offense, and legally a sin (haram) or reprehensible (makrooh), to doubt food provided by a fellow Muslim. If non-halal food is unintentionally consumed, the sin for transgression accrues to the devious supplier. In cases where both supplier and consumer are unaware of the transgression of halal then both are immune from blame. Integral to this practice of halal is the centrality of niyyat (intention) for the production of trust. The proper intention to consume halal within Muslim networks of trade and exchange ensures compliance, while unintentional transgression is of much lesser concern. This communally charged notion of trust is ripe for sectarian division and conflict, but it always foregrounds halal as a matter of consuming and trading within a network of Muslim butchers, traders and suppliers. Signs of identity - including names, images and dress - mark the partners in exchange as Muslim and index the food they proffer as halal. The materiality of the substance consumed remains mostly out of view.

In contrast, halal certification is a recent development initiated during the 1970s by the Malaysian government, as part of its Islamization efforts, targeting both domestic middle-class consumption and the needs of Muslim minority populations in Europe (Fischer 2011: 35). During the 1980s and 199os with the expansion of global trade, halal certification organizations became increasingly prominent. The global scale and scope of trade introduced opacity to what was previously a locally based food supply chain. The possibility for intra-Muslim trade and consumption became complicated as Muslims became consumers in a global market. Developments in food technology, consumer access to information, and the shift towards a 'risk society' (Beck 1992) mean that middle-class Muslims around the world have become increasingly aware of the complex nature of food production and supply.

Global supply chains and the complexity and opacity of food technology introduces new risks and opportunities for halal. With imported meat and commercial slaughter, the local Muslim butcher no longer possesses intimate knowledge of the meat production process. Mass consumption and processed food means that Muslims purchase products manufactured using enzymes, colorants and flavorants that may be of animal origin. In the process, meat sold by Muslim butchers and even non-meat products such as chocolates and bottled water may now become subject to halal concern. 
Halal certification organizations produce guidelines, auditing procedures and documentation to assure halal consumption on a global scale. DNA tests and supply chain management promise to establish material certainty over the substance of halal in order to facilitate trade and consumption beyond Muslim networks. Middle-class Muslim consumers survey halal information, check cell phone applications and conduct independent research in a bid to investigate and regulate their own consumption in non-Muslim contexts. However, the process through which halal certification has emerged has not been a straightforward response to the new material conditions of food production and global trade. For example, in South Africa the demand for halal certification depends on a certification industry risk discourse that demystifies the complexity of global supply chains and food technology in articulating halal certification as a necessity for Muslim consumption (Tayob 2012, 2016). Similarly for Malaysia, Johan Fischer has shown how the establishment of halal certification as an audit culture entails the same process whereby the state employs new forms of scientific knowledge in the regulation and investigation of halal, communicates risky aspects of contemporary food production to an unsuspecting public, and establishes certification as the solution (Fischer 2016).

Given the importance of Muslim networks of trade and exchange for the practice of halal, the shift towards risk and the standardization of halal certification has not been uncontested. As we will see the discursive tradition of halal based on intra-Muslim networks of trade and exchange is not erased under new conditions of complex food production and global trade. Halal certification organizations in South Africa continue to rely on Muslim identity in the very process of regulating halal. The importance of Muslim identity in turn offers a recourse for Muslim business to evade central tenets of halal certification industry practice.

\section{Halal Certification: Standardization, Sectarianism and Market Competition in South Africa}

The history of halal certification in South Africa offers a unique case through which to appreciate the prevalence of debate and contestation that has continued to accompany the drive towards standardization. The establishment and practices of the competing halal certification organizations testify to the continued relevance of the discursive tradition of halal, now transformed by the new imperatives of food technology and global trade.

Halal certification has a long history in South Africa. In 1958 the Western Cape Muslim Butchers Association (WMBA) approached the Muslim Judicial 
Council (MJC) for 'theological backing' for its slaughter procedures. The resulting partnership between the butchers and ulama gave rise to the first halal assurance agreement in the country. During the 1970s similar arrangements were established by the Witwatersrand Muslim Butchers Association in the north of the country, in a bid to ensure the reliable supply of halal meat to the small but economically significant Muslim community (Cassimjee 2004: 101-111). In both regions, Muslim butchers were afforded exclusive shifts at the municipal abattoir during which halal slaughter was performed. Before each halal shift, the area was cleaned under the direction of Muslim butchers. There were quotas on the number of halal-slaughtered animals processed during each shift. At this stage, no halal certificates were issued. Rather, member butchers displayed certificates of membership that testified to the origin of all meat sold.

During the early 1980 o the WMBA and the MJC entered into conflict over the MJC plan to supply non-Muslim retailers with halal slaughtered meat. The butchers considered halal meat to be their exclusive prerogative, but the ulama argued that halal meat should be supplied to non-Muslim-owned national chain stores. The conflict of interest signaled the early signs of a fundamental shift in halal practice from the exclusivity of Muslim networks of trade to public mass consumption.

The Wм BA split from the MJC and approached the newly formed Islamic Council of South Africa (ICSA) for ulama support. ICSA was led by Shaykh Abu Bakr Najjar (d. 1992), a prominent local imam who had been a halal inspector for the MJC. At this stage competition over halal supply was still limited to meat, but in 1985 the first halal certificate for a non-meat product was issued - for Flora margarine. The margarine certification contract emerged from the discovery of the use of gelatin in the manufacturing process of margarine. The MJC issued a well-publicized fatwa that ruled on the permissibility of gelatin consumption from non-halal sources and obtained the certification contract (Tayob 2019). The certification of this margarine signaled the first concern with food technology and halal in South Africa.

After apartheid, freedom of movement for the previously oppressed Muslim community, along with the liberalization of the meat industry further complicated the demand for and supply of halal. Muslims from various sectarian and ethnic backgrounds began to demand halal food in places previously off-limits such as fast food chains, hotels and workplaces. In 1996 the South African National Halal Authority (SAN HA) was established to cater to the new demand for halal in non-Muslim food production contexts. SANHA was an organization headed by Deobandi- and Barelvi-aligned ulama that brought ulama organizations, business leaders and the Witwatersrand Muslim Butchers 
Association (WMBA) together in a bid to create a standardized national halal authority. The Deobandi school is a 19th century reform movement founded in Deoband, India, whose adherents claim a return to orthodoxy and proper ritual practice as a solution to what they see as the deviant practices of contemporary Muslims. They are known for a vehement critique of popular Sufi practices of shrine visitation and intercession (Metcalf 1978; Moosa 1997). The Barelvi are a competing reform movement founded in Bareilly, India, that offers scriptural justification for popular Sufi practices. Both have a strong base in South Africa with conflict occasionally leading to violent outcomes (Vahed 2003). After an initial period of cooperation, a conflict emerged over the management and regulation of halal. SANHA is uncompromising in its approach to halal certification, actively seeking to illuminate potential halal contraventions to an unsuspecting Muslim public. The WMBA and Barelvi ulama frown upon the aggressive promotion of halal certification. For them the active promotion of risk to halal leads to unnecessary consumer anxiety and intra-Muslim conflict. These organizations each embody a different approach to the relationship between halal practice and halal certification. The WMBA aligned with the Barelvi ulama to form the National Independent Halal Trust (NIHT). It is clear from the organization's name that it too aspires toward the development of uniform national standards. However, the prevalence of intra-Muslim sectarian difference, competing halal organizations and ulama-butcher conflicts means that standardization remains an industry goal rather than everyday practice.

The remainder of this paper focuses on SANHA and NIHT. Both organizations have a significant presence among the middle-class Indian populations centered around Durban and Johannesburg. SANHA has been a prominent voice in the articulation of a new practice of what I call 'molecular halal' that emphasizes the opacity of halal risk and presents certification as the only option for halal practice in a complex world of food technology and global trade. NIHT has been similarly prominent in the reach of its certification initiatives, focusing on the certification of national fast food chains and corporate food producers. Both organizations focus on halal certification to facilitate Muslim public consumption, yet each embodies a different calibration of how halal certification is formulated. That is, each articulates a different relation between the historical practice of halal based on intra-Muslim trade and exchange with a new impetus towards material certainty. Even in impersonal markets and global trade, maintaining Muslim identity in trade and consumption relations remains a central practice. It is important to note that halal certification is not the only way to structure trust in the contemporary world; it is not an inevitable development of halal practice. 


\section{The South African National Halal Authority: a Risk Discourse}

SANHA has been central to the promotion of halal certification in South Africa. As a founding member of the World Halal Council it has played a major role in establishing standards for halal certification in both South Africa and India and offers an important insight into the global development of halal certification. SANHA has taken the lead in promoting the necessity of halal certification through an aggressive publication initiative that highlights the contemporary halal risks to an unsuspecting and complacent Muslim public. For example, SANHA insists that the common practice of maintaining halal by consuming vegetarian food at a non-halal certified restaurants is unacceptable. For SANHA, the complexity of food technology and cross-contamination render even the homes of Muslim friends and family suspect, unless goods intended for consumption have been certified. SANHA articulates halal certified consumption as an Islamic imperative, a new injunction for the consuming Muslim in a globally integrated and complex world (Tayob 2016).

SANHA discourse reiterates the necessity of professionalism, organizational procedures and industry knowledge for halal certification. In a 2010 interview with the theological director, Mr. Navlakhi, he explained the basis for the SANHA approach to certification to me. Drawing on the business operations management language of 'critical control points' he explained the intimate link between expert industry knowledge and the practice of halal certification. For Navlakhi halal certification is comparable to financial audit in that 'you cannot regulate the industry if you do not understand the mechanics of that industry'. He thus stresses the need to understand supply chain management and food production processes in order to establish halal critical control points as locations for potential risk.

The SANHA approach has been inspired by its involvement with global halal organizations in Indonesia and Malaysia. SANHA's approach is also inseparable from its competition in the South African halal certification market. For example, in 2001, in one of its earliest publications, SANHA attacked what it considered to be MJC's ignorance of the use of animal extracts and enzymes in the potato chip production process (Tayob 2016: 79). Such an emphasis on expert knowledge and institutional efficiency has been central to SANHA's prominence and popularity in South Africa. It distinguishes itself as an exemplar of professionalism and procedural excellence in regulating halal certification, and in a short period of time it became the largest certification organization in South Africa in terms of revenue. It has succeeded in convincing many Muslims of Indian origin and Deobandi affiliation, in particular, that its standards of halal are exemplary and uniquely trustworthy. Through consumer 
information, advertising, critique of competitors and a sustained emphasis on the necessity of halal certification, SANHA has managed to create brand awareness claiming superiority for its halal certification standards and procedures.

The focus on procedural expertise and organizational competence as a source of trust is never completely dissociated from the importance of Muslim presence in the food production and service industry. In order to obtain certification, an outlet or manufacturing plant has to maintain a quota of Muslim employees on site at all times. This is considered the first line of assurance of halal. The Executive Officer of SANHA, Mr. Mahomedy, explained the process for the halal certification of a restaurant.

Now our policy in SANHA is, firstly, we don't certify non-Muslim restaurants. Number two, we do certify one or two in certain areas where there is a need for the Muslim community. If you take Richards's Bay now, there are no Muslim restaurants in that area. Then an application came, and then we said these are our criteria. For each shop we need two people that must be Muslim supervisors, paid by SANHA. You (the applicant) will reimburse us. It's not that you (the applicant) will pay them, you will keep them, and they will carry on. They go through us and they have to submit reports on a weekly basis to us.

What must be noted is that SANHA's usual emphasis on material certainty does not mean that non-Muslims can be granted halal certification if their products are halal by all technical requirements. Only in the case that there are no Muslim-owned restaurants, can a non-Muslim-owned one receive halal certification. Even then, Muslim employees - or rather permanent inspectors - are required. They are to be employed and trained by SANHA to perform their restaurant duties.

The need to certify a non-Muslim-owned restaurant points to the intimacy of halal certification and public consumption. The employment arrangement maintains audit independence from the applicant business. Meanwhile, Mr. Mahomedy appeals to the caveat of necessity (darura) in Islamic law that allows for transgression in the absence of an alternative (Ibrahim 2015). The 'new' certification procedures are thus a recalibrated discursive tradition with the stipulation of Muslim presence and the appeal to necessity referencing historical traditions of halal practice.

As I learned further, not any Muslim will do as an employee in a halal certified business. The employee must be a certification-trained, compliance-reporting Muslim subject who combines technical proficiency with a particular notion of how to be a good Muslim. Mr. Mahomedy explained: 
The inspectors actually have 93 duties and guidelines, for SANHA inspectors, a code of conduct governing us as Muslims. Your requirement as a Muslim, what you have to do. What's your do's, what's your don'ts. The loyalty commitment to SAN HA. Responsibility. Allocation of plants and outlets. Then the preparation for inspections. Conducting of the inspections, completion of the forms, behavior while conducting inspection, concluding the inspection. Then you have here duties and guidelines for SANHA supervisors on the plant. His attire, his uniform, his attendance, his leave, his hygiene, personal hygiene, hygiene at the plant, hygiene of your office area and ablution facility, confidentiality documentation, conformity to company policies, gifts and items you can't receive, professionalism....

The SANHA guidelines and duties for inspectors highlight corporate professionalism, employee duties and proper Muslim behavior. Most SANHA inspectors are trained ulama who have sought a career in halal certification. The emphasis on Muslim duty and dress thus points to a mode of behavior that brings Muslim identity and virtuous practice in line with procedural compliance and a brand image. SANHA inspectors are expected to appear, behave and present an image of Muslimness that will inspire trust in the organization and its halal certification credentials.

Muslim ownership and oversight links the new practice of halal certification to an established discursive tradition of halal and intra-Muslim trade. However, the new conditions of 'molecular halal' (Tayob 2019) that render expert intervention and certification necessary, also anticipate that Muslimowned businesses are otherwise ignorant of halal transgression. Recounting the early phase of halal certification in South Africa, and the necessity of halal certification for Muslim businesses, Mr. Mahomedy drew out the widespread potential for unknowing transgressions.

Steers, one of the Steers (burger franchise). They said that they don't want to have SAN HA nonsense, why must I pay R30o. Somehow, we convinced him, 'let's have a meeting and discussion with you.' He said 'okay'. We walked in there. Now we're talking about his restaurant, we're sitting there having this meeting and he is not concerned with who the customer is ... and a guy walks to the counter and he said, 'there is no halal certificate here?' We didn't even know who that guy was, it was a remote area. The owner of the business just looked at him. And then we continued and then we went on an inspection into the kitchen. We inspected the brush ... pork bristles. Now he didn't know, but he was anti-certification, and he was feeding the ummah with haram. And in a bakery .... I walked 
into a bakery and I told the guy I will give $\mathrm{R}_{5} 000$ charity and you give a Riooo charity if I don't find anything. If I find something you give Riooo charity. He said 'it's on'. I walked in and I said, 'may I see your basting brushes please'. So, there it is - pork bristle. In a Muslim home the same thing is happening.

The publication of the use of pork bristles in restaurants and homes shocked many South African Muslims as it presented evidence of unknown intimacy with a taboo item. For SANHA it offered a clear example that Muslim involvement in the supply, transport and preparation of food was no longer sufficient for halal practice. The issue became central to its publication campaign (Tayob 2016: 82).

Historically there have been differences of opinion regarding the use of pig hair. Some scholars have insisted that the entire pig is impure, while others have argued that the hair is permissible for use. With South African halal certification, this nuance is elided in favor of unanimous agreement that all pig products are not halal. The SANHA advertising initiative appeals not to legal technicalities but rather to a visceral sense of disgust and repulsion that many Muslims have for pork and pig products.

In Mr. Mahomedy's narrative we obtain insight into another side of the SANHA pork bristle campaign. Here, a Muslim owner, critical of halal certification, is faced both with evidence of Muslim consumer demand for halal certification and the 'discovery' of pig-hair basting brushes in his kitchen. Similar to the incident in the bakery, it is clear that Mr. Mahomedy was already aware of the potential halal contravention. The meeting and charity gamble with the owners was set-up less to investigate the halal status of the store than to illustrate to Muslim businessmen their own ignorance of the expanded conditions of halal promoted by certification.

SANHA relies on the professionalism of a Muslim halal inspector, armed with an arsenal of information on the opacity of halal, and sufficiently trained in corporate procedure and their own version of Islamic ethics, to engender trust in certification. Other organizations are also staffed by Muslims, but SANHA critiques these 'untrained' employees as potentially guilty, ignorant of the now invisible risks to halal. This means that SANHA refuses to accept the halal status of products certified by a competing organization until it has conducted its own audit of the manufacturer premises. SANHA-certified businesses may only source ingredients from other SANHA-certified or SANHA-approved suppliers. SANHA exclusivity is a topic of concern for Muslim businesses who - although increasingly aware of the necessity of halal certification - continue to conceptualize and practice halal through forms of intra-Muslim trade. 


\section{NIHT: Risk, Procedure and Community Service}

NIHT was formed after the Witwatersrand Muslim Butchers Association and the Barelvi ulama split from SANHA to form a new halal certification organization. NIHT also emphasizes the importance of documentation, procedure and expert knowledge in its nationwide regulation of halal. Its focus is similar to SANHA in that it aims to facilitate Muslim public consumption in a changing world. NIHT's primary operating emphasis is on corporate food producers and national chain stores which - so it explains - are increasingly important for Muslim consumption given the prevalence of dual income households and changing consumer lifestyles. The organization employs an in-house food technologist and has close ties to university food scientists in South Africa.

Mowlana Hookay, the CEO of NIHT, explained why the split from SANHA took place. He said the SANHA approach to halal certification is excessively aggressive and uncompromising. An issue for Mowlana Hookay is 'a difference of opinion in terms of how you would operate in terms of other certification bodies'. He was referring to SANHA's practice of not accepting halal certification from competing organizations until its own inspectors had conducted a full halal audit of the potential supplier premises. For NIHT, such skepticism contravened the basic principle of trust as a component of intra-Muslim trade. NIHT accepts supplies from other certified sources if the procedures of the competing organization are 'found to be acceptable according to the standard that has been drafted nationally'. In the event that all documentation surrounding procedural compliance is found to be in order, no site inspection of the competing organization is considered necessary. The NIHT incorporates the Muslim identity of competing organizations into its conception of a standardized audit procedure. For NIHT, halal certification is a new articulation of intra-Muslim networks, now produced through shared adherence to audit procedure.

NIHT differs from SANHA on the certification of Muslim-owned businesses. In financial auditing, risk management and control is central to practice. Risky areas of financial mismanagement are identified and procedures established to mitigate and test for potential contravention. With halal certification, a similar process is applied to the production, management and retail of halal food. SANHA argues that the new opacity of halal renders the identity of Muslim businessmen insufficient for halal assurance. In contrast, NIHT incorporates the Muslim identity of its clients into its risk assessment procedure. During a 2017 research trip to Johannesburg, Mowlana Hookay explained that if a Muslim meat wholesaler approaches NIHT for certification, and it is clear that the business does not use any chemicals or other food technology ingredients, 
then the business is considered to be 'low risk'. In this case, a site inspection may not be necessary since the testimony of the Muslim supplier regarding the absence of non-halal substances on premises is combined with a risk assessment of the nature of the business concerned. NIHT understands its interactions with the Muslim community through a commitment to intra-Muslim trade in a minority context.

Our approach is this here. The service that we are providing is for the Muslim ummah at large, the ummah is inclusive of Muslim businessmen and the consumer. The Muslim businessman, it is compulsory for him to sell halal, you understand, as opposed to a non-Muslim businessman who doesn't have to sell halal. So that puts the Muslim businessmen at a slight - I wouldn't say disadvantage because there is a lot of barakat (divine blessings) in selling halal - but his consumer base is not as open as maybe the Pick n Pay and all these guys.

According to Mowlana Hookay, NIHT has two main constituencies for which it provides its services, the Muslim businessmen and the Muslim consumer. He argues for the Muslim businessmen's position as a provider of halal as a limiting factor in his business interests in a minority context. For example, in South Africa it is widely known that restaurants that serve alcohol or pork products are able to attract a much wider clientele. Quick to not discount the blessings of halal trade, he clearly expresses an awareness of market dynamics in a minority context. For Hookay this assessment is inseparable from the welfare function he associates with South African Muslim business.

We live in a country where as Muslims we need to fend for ourselves. So we need to fend for ourselves in terms of zakat (alms, charity), we need to fend for ourselves in terms of things like masajid (places of worship), we need to fend for ourselves in terms of whatever it is that we do for the Muslim ummah. And the people that fund all of this is the Muslim businessmen. Whether he is running Amka (a large Muslim-owned corporation), whether he is running a small corner shop. So we need to look at things in terms of where is it the zakat is going, it's going to the Muslim community. But funding is coming for the Islamic activities from these Muslim businessmen. So, we don't over-tax the Muslim businessmen. We don't over charge. We are somewhat lenient towards Muslim businessmen.

Situating the South African Indian Muslim minority context, Hookay relates the importance of alms for the establishment of places of worship, as well as 
for outreach and welfare activities. Translating zakat into a kind of Muslim welfare tax, he recognizes the importance of Muslim businesspeople as significant donors. The affinity between businessmen and religious organizations among the Indian-origin communities in South Africa has a long history (Tayob 1999). Moreover halal certification has a cost beyond its announced fees. NIHT recognizes that it must accord some leniency to Muslim businessmen for them to be successful enough to sponsor the ummah. NIHT relies on the identity and conscience of Muslim businessmen as 'Muslim businessmen' to provide a level of halal assurance.

In the sense that they need to take care of halal, and because they are Muslim. They have a conscience, remember he is a Muslim businessman. He is a Muslim, you understand. So he needs to take cognizance of what is halal, more than just having a halal certificate, and saying, you know, the onus is on the organization. No, as a Muslim businessman, the onus is on you. And there are many ahadith (narrations attributed to the Prophet Muhammad) that talk about being a proper businessman.

For Hookay, halal certification is not an end in itself. It is a service that facilitates Muslim consumption and trade. For consumers, halal certification ensures that they are able to access the convenience of public consumption. For businesses, halal certification ensures they are able to compete in a world of increasingly complex local and global trade. For example, since many national chain stores have obtained halal certification in a bid to access the Muslim consumer market, Muslim businesses who wish to enter into supply arrangements also require halal certification. NIHT maintains the importance of intra-Muslim trade and exchange for halal now as the communal importance of facilitating Muslim business practices in an increasingly complex and competitive world. Invoking the identity, conscience and moral obligation of Muslim businessmen, NIHT engages the discursive tradition of halal as communal trade.

\section{Muslim Business Practice: Intra-Muslim Trade and Exchange}

In the competitive halal industry in South Africa, businesses are free to seek certification from any of several organizations. SANHA certification means sourcing ingredients from SANHA-certified suppliers, a restriction which NIHT does not require. However, SANHA has developed a staunch following through its extensive promotion of its certification procedure as superior to that of 
all competitors. SANHA followers refuse to consume at non-SANHA certified outlets or purchase non-SANHA certified products. For businesses, an assessment of market demand is important when choosing a halal certification organization.

Here I present a vignette of a Muslim business based in Johannesburg. This example provides insight into how the practice of halal rooted in intra-Muslim trade and exchange continues to inform halal business practice even in increasingly impersonal markets. It is not meant as a claim of completeness, but rather an example of an incredibly common practice wherein Muslim businesses interact and trade on the basis of Muslim identity not certification.

Mohsien has, during the past two years, established an online meat wholesale and retail delivery company. In seeking halal certification, he approached both SANHA and NIHT. Given the presence of SANHA-only customers it was his first option. SANHA presented him with a substantial information-request list regarding his product lines, storage facilities, transport methods and customers. As a start-up eager to protect his small market share and with no fixed employees, he was annoyed by the barrage of questions and the significant audit fee. NIHT determined that since he is merely a conduit between wholesalers, butchers and customers, his risk for halal transgression is low. He does not deal in pork products and all of his meat is sourced from halal certified suppliers and delivered in vacuum-sealed packaging. Mohsien received a halal certificate from NIHT at a nominal fee and without a site inspection.

As an NIHT-certified meat supplier, however, Mohsien is always wary of potential SANHA certified clients with whom he cannot trade. Mohsien has recently grown his business and identified a market for de-boned lamb shanks. He is able to source de-boned lamb shanks from a supplier for far less than his potential client, a local Muslim-owned food caterer, and the caterer is happy to buy from him. However, the caterer is SANHA-certified and Mohsien is not. According to the SANHA certification procedure, the caterer needs to notify SANHA of the new supplier. SANHA will then conduct an independent audit of Mohsien's business process and premises before authorizing him as a SANHA-approved (though not certified) supplier. The two businesses would seem to have reached an impasse because the caterer did not want to incur the additional costs for SANHA's authorization.

Nevertheless, they found a solution. The caterer trusts that Mohsien, a Muslim meat wholesaler, is a reliable source for halal lamb. After some negotiation over price and the reliability of supply, the caterer gave Mohsien instructions for re-delivering the meat. When the de-boned lamb shanks arrived, he should 'just receive the packages, remove the box lids, and then deliver'. This is 
what Mohsien does. He removes the box lids which bear the NIHT halal logo and supplies the vacuum-sealed products onwards to the caterer. If a halal inspector arrives on-site for a random inspection, the caterer will explain that the items have in-fact been sourced from a SANHA certified supplier.

The ease of transgression is not an indication of a lapse in SANHA organizational integrity. Halal certification, like financial auditing, is always likely to be circumvented through creative documentary practice. The difference is that with financial audit the circumvention of controls is usually aimed at achieving fraudulent gains. Here the circumvention of the audit is not considered to affect the halal quality of the goods exchanged. Mohsien and the caterer are both Muslim businessmen, halal certified and committed to the halal trade in meat. They consider the trade and exchange of meat between Muslims to be the primary practice of halal. For them, halal certification is necessary primarily if non-Muslim intermediaries are involved in the supply or retail of halal meat. In this arrangement, however, both are Muslim-owned businesses and they are confident that circumventing SANHA's procedures helps them maintain a lucrative and trustworthy exchange of halal. They engage in trade with each other as fellow Muslims, not as anonymous rational agents. In practicing halal, they continue to subscribe to a discursive tradition of intra-Muslim trade and exchange even in increasingly impersonal markets.

\section{Conclusion: Halal Certification in Practice}

Halal certification does not erase the importance of Muslim identity, subjectivity and intra-Muslim networks of trade for halal. Halal certification organizations engage a discursive tradition of halal in formulating halal certification practices and procedures. The application of audit cultures to understanding the practice of contemporary halal fails to capture the complexity of Islam as a discursive tradition and the importance of context, debate and contestation. Emphasizing the standardization of halal merely reproduces the stated halal certification industry goals. This paper has offered a corrective by drawing attention to the complexity of halal certification practice in the South African minority context.

Halal certification transforms the practice of halal in complex ways. Sectarian differences, market dynamics and contextual assessments by certification organizations remain important in understanding the practice of halal certification. For both SANHA and NIHT, aspects of Muslim identity and Muslim subjectivity remain central to halal certification in practice. SANHA comes closest to an abstract emphasis on procedure and documentation. It 
focuses on a new kind of halal certification subjectivity for contemporary halal. NIHT positions itself as a service provider for the Muslim minority community, engaging in a situated analysis of certification as taxation and Muslim businesses as welfare providers. Included in the NIHT risk assessment practice is a consideration of the conscience and identity of Muslim businesses. Neither organization engages in a complete abstraction of halal from Muslim networks of trade. Halal certification aims to recalibrate Muslim networks, inserting halal certification organizations as the mediators of halal. Muslim businesses do not always share the aim and approach of halal certification organizations. As practitioners and suppliers of halal they are likely to take recourse to trust in intra-Muslim networks of trade that do not align with the procedural and documentary aims of the halal certification industry.

The developments in global trade and food technology that mark the past few decades are incredibly recent given the long history of halal practice. As developments in halal certification research continues, it is important to pay close attention to the practices of the halal certification industry and Muslim consumers and businesses as they engage a discursive tradition of halal in creative and complicated ways. I argue that the recourse to intra-Muslim trade as a basis for trust in halal is far more widespread than currently acknowledged in the halal certification literature. Intra-Muslim trade and exchange challenges the documentary and standardization impetus of halal certification. It continues as an important basis for consumption and trade even in increasingly complex markets.

\section{Acknowledgements}

This paper is based on research in part funded by the National Research Foundation of South Africa (Reference Number [UID] 85397) and the Max Planck Institute for the Study of Religious and Ethnic Diversity in Gottingen, Germany. The opinions expressed herein are that of the author, not the funding institutions. Special thanks are due to the anonymous reviewers and copyeditor Jennifer Cash for the close reading and useful feedback.

\section{References}

Asad, T. (1986). The Idea of an Anthropology of Islam. Washington, D.C.: Center for Contemporary Arab Studies, Georgetown University. 
Bear, L. (2011). Making a river of gold: Speculative state planning, informality, and neoliberal governance on the Hooghly. Focaal - Journal of Global and Historical Anthropology, 61: 46-6o.

Bear, L. (2013). The antinomies of audit: opacity, instability and charisma in the economic governance of a Hooghly shipyard. Economy and Society, 42: 375-397.

Beck, U. (1992). Risk Society: Towards a New Modernity. London. Sage Publications.

Bonne, K. \& W. Verbeke (2008). Religious values informing halal meat production and the control and delivery of halal credence quality. Agriculture and Human Values, 25: $35^{-47}$.

Cassimjee, I. (2004). The Concept of Halal and Haram in Relation to the Muslim Diet: A Historical Case Study for the Establishment of Halal Authorities in South Africa. Masters Thesis, University of KwaZulu-Natal.

Cook, M. (1986). Early Islamic dietary law. Jerusalem Studies in Arabic and Islam, 7: 218-277.

Fischer, J. (2011). The Halal Frontier: Muslim Consumers in a Globalized Market. New York: Palgrave Macmillan.

Fischer, J. (2016). Islam, Standards, and Technoscience: In Global Halal Zones. New York and London: Routledge.

Foucault, M. (2007). Security, Territory, Population: Lectures at the College De France. New York: Palgrave Macmillan.

Freidenreich, D.M. (2011). Foreigners and their Food: Constructing Otherness in Jewish, Christian and Islamic Law. Berkeley: University of California Press.

Gillette, M.B. (2005). Children's Food and Islamic Dietary Restrictions in Xi'an. In, J.L. CaldwellWatson \& M.L. (eds.), The Cultural Politics of Food and Eating: A Reader, pp. 106-121. Malden: Blackwell Publishing.

Ibrahim, A.F. (2015). Pragmatism in Islamic Law: A Social and Intellectual History. Syracuse: Syracuse University Press.

Marranci, G. (2012). Defensive or offensive dining? Halal dining practices among Malay Muslim Singaporeans and their effects on integration. The Australian Journal of Anthropology, 23: 84-100.

Metcalf, B.D. (1978). The Madrasa at Deoband: A model for religious education in modern India. Modern Asian Studies, 12: 111-134.

Moosa, E. (1997). Worlds 'apart': Tablighi Jama'at in South Africa under apartheid, 19631993. Journal for Islamic Studies, 17: 28-48.

Power, M. (1996). Making things auditable. Accounting, Organisations and Society, 21: 289-315.

Schoeman, W.J. (2017). South African religious demography: The 2013 General Household Survey. HTS Teologiese Studies/Theological Studies, 73:1-7.

Shore, C. \& S. Wright (1999). Audit culture and anthropology: Neo-liberalism in British higher education. Journal of the Royal Anthropological Institute, 5: 557-575. 
Strathern, M. (200o). Introduction: New accountabilities. In M. Strathern (ed.), Audit Cultures: Anthropological Studies in Accountability, Ethics and the Academy, pp. 1-18. London and New York: Routledge.

Tayob, A. (1999). Islam in South Africa: Mosques, Imams, and Sermons. Gainesville: University Press of Florida.

Tayob, S. (2016). O you who believe, eat of the tayyibāt (pure and wholesome food) which we have provided you' - The role of risk and expertise in producing certified halal consumption in South Africa. Journal of Religion in Africa, 46: 67-91.

Tayob, S. (2019). Molecular halal: Producing, debating and evading halal certification in South Africa. In , K. HauserDmitriev, J. \& B. Orfali (eds.), Insatiable Appetite: Food as Cultural Signifier in the Middle East and Beyond, pp. 100-118. Leiden and Boston: Brill.

Tayob, S. (2012). Consuming, Producing, Defining Halal: Halal Authorities and Muslim Consumers in South Africa. Masters Thesis, University of Cape Town.

Vahed, G. (2003). Contesting 'orthodoxy': the Tablighi-Sunni conflict among South African Muslims in the 1970s and 1980s. Journal of Muslim Minority Affairs, 23: 313-334.

Woong, L. (2007). Market cultures, the middle classes and Islam: Consuming the market? Consumption Markets \& Culture, 10: 451-48o. 